\title{
Analysis of Xi Jinping's Quality Thought from the Perspective of Content Analysis Method based on Analysis of 42 Quality Policy Texts
}

\author{
Zhao-Rui FENG, Chang CHEN \\ Management and Economics Institute \\ Kunming University of Science and Technology \\ Yunnan Province, China
}

\begin{abstract}
In the critical period of optimizing economic structure, transforming mode of economic development and growing economic development about endogenous dynamics, deep analysis of $\mathrm{Xi}$ Jinping's quality thought, which guides structural reform for supply side, deepens social perception of the concept of which quality makes the country strong and promotes the development of Chinese quality and realizes the road of the "two hundred years" and the Chinese dream of the great rejuvenation, has highly practical significance. By establishing a two-dimensional framework of tool-value chain, this paper quantitatively analyzes $X i$ Jinping's narratives about quality problems by using content analysis method. It is concluded that $\mathrm{Xi}$ Jinping focuses on the application of environmental and demand-oriented policy tools during implementation of the strategy of "quality is strong". The quality of poverty alleviation and the quality of policy quality are outstanding. The scientific and systematic planning and summary of issues, such as poverty alleviation, economic development and construction of quality laws and regulations within the party, are emphasized. It emphasizes the promotion of high-quality economic development, steadfastly promoting poverty alleviation and tackling key problems and advocates taking spiritual poverty alleviation, endogenous poverty alleviation and scientific poverty alleviation as the main contents. That provides strongly theoretical basis and policy compliance for achieving the goal of strengthening the country with quality.
\end{abstract}

Keywords-Xi Jinping, quality thought, content analysis, the power of quality

\section{INTRODUCTION}

In the fierce and international market environment of the 21st century, the war of numbers has been transformed into quality and differentiated war. More and more countries are participating in competition about quality. In order to comply with the trend of quality development of the times and realize the transformation of "big manufacturing country" and "weak brand country" to a country of powerful quality, since the 18th National Congress of the Communist Party of China, the party central committee with comrade $\mathrm{Xi}$ Jinping as the core has learned the general trend of development and grasped the law of development. They put quality in an unprecedentedly important position and have made a series of major decision-making arrangements for quality work.[1]
In order to deeply understand the essence of Xi Jinping's quality thoughts and provide strongly theoretical compliance for building country of quality, this paper has collected more than 300 articles from the 18th National Congress and selected 42 representative documents or reports. Through the quantitative analysis of 42 texts, the scientific system summarizes the essence of the spirit of general secretary $X i$ Jinping and provides reliable and theoretical basis for improving the ecological quality, economic quality, legal quality and poverty alleviation quality in order to meet global economic transformation, domestic upgrades of industry, human and urgent need for quality life. It will inject powerful force.

\section{The ORIGIN OF Xi JinPING'S QUALITY ThOUghT}

Since the 18th National Congress of the Communist Party of China, continuous innovation of $\mathrm{Xi}$ Jinping's quality thinking content and form has been largely due to acceleration of the international market for quality developmental trend, the development of the global integration situation and the advent of modern era. Tracing back to the source, the ideological achievement of Marx, Engels and Lenin in the field of quality are the source of the continuous development of Xi Jinping's quality thought.

\section{A. The Influence of Marx and Engels on Xi Jinping's Quality Thoughts}

At the stage when the commodity economy has just entered a stage of prosperity, the concepts advocated by Marx and Engels, which includes quality testing, product quality determining success or failure of trading and those high-quality goods are easy to gain advantages during international transactions, are deeply in the spirit of Xi Jinping's quality. Later, $X i$ Jinping put forward new ideas on strengthening China's foreign trade advantage and encouraging enterprises to improve the quality inspection level of commodities.

\section{B. The influence of Lenin on Xi Jinping's quality thought}

Lenin's inspiration for $X i$ Jinping's thoughts about quality is mainly reflected in the reform of state organs and the improvement of the quality of party members. When reforming government offices, Lenin insisted on the principle of "Quantity should be less, but higher quality", emphasizing the importance of quality while also paying attention to quantity. At the time of the 18th National Congress on national 
governance issues, inspired by this thought, $X i$ Jinping proposed to deepen the institutional reform of the state council and improve the quality and level of modernization of the state. Similarly, Xi Jinping and Lenin have a high degree of resonance in work within the party. They advocate high-quality selection of party members and improve the structure and quality of party members. Xi Jinping's quality thought is based on the absorption of the early quality concept of Marx. And the predecessor's quality viewpoint is given the Chinese characteristics of the times and $X i$ Jinping's new era quality thought of socialism with Chinese characteristics has formed. That has laid a solid ideological foundation for China's quality development.

\section{OVERVIEW OF CONTENT ANALYSIS}

Content analysis is a method of comprehensive research that combines the scientific and precise nature of quantitative research with the exploratory and predictive nature of qualitative research. Therefore, the results obtained according to this research method are very convincing and strictly guarantee the objectivity of the research is the characteristic of the content analysis method.

The method of content analysis can be divided into ten stages, which are determining the research problem or hypothesis, determining the research population, objective sampling, selecting the analysis unit, constructing the category system, constructing the quantitative system, encoding the content, analyzing the data and explaining the results and the reliability and validity of the article.[4]

\section{ANALYSIS OF THE CONNOTATION OF XI JiNPING'S QUALITY THOUGHT FROM THE PERSPECTIVE OF CONTENT ANALYSIS}

The 21st century is an era of quality. Quality issues are more closely linked to national development and people's livelihood. Since the 18th National Congress of the Communist Party of China, in the process of pushing economic development from the speed era to the quality era, president $X i$ Jinping has stood at the height of strategy and put forward many new arguments and new ideas on quality development from the perspective of state governance. That formed $X i$ Jinping's quality ideology with rich connotation and distinctive features. As an important part of the latest theoretical achievements of socialism with Chinese characteristics, it provides practical and theoretical guidance for the formulation of China's quality policy and points out a scientific realization path for quality development.

Since the reform and opening up, China's quality work has been steadily moving forward. The party central committee with $X i$ Jinping as the core puts quality development in a strategic position and has published a series of important expositions on quality. On May 10, 2014, General Secretary Xi Jinping proposed a great "three major changes", which pointed out the direction of China's quality development and caused a strong response from the whole society. At the 2015 Central Economic Work Conference, when addressing the structural reform of the supply side, General Secretary $X i$ Jinping emphasized that it is necessary to expand and meet consumer demand by creating new supply and improving supply quality. On January 18, 2016, at the spirit seminar of the fifth plenary session of the 18th CPC Central Committee, General Secretary $X i$ Jinping pointed out the issue of structural reform on the supply side once again and emphasized the importance of placing food safety in a prominent position. In 2017, the central government officially issued the first quality work program document formulated by the party central committee and the state council in the history of China's quality development. At the time of the 19th National Congress of the Communist Party of China, according to the mainly political judgment that the main contradictions in our society have changed, $\mathrm{Xi}$ Jinping explicitly mentioned the concept of "quality is strong" and "quality is in priority", calling on all provinces, cities and counties to carry out actions of improving quality and comprehensively upgrade China in order to improve the overall quality of China's overall quality.

Through quantitative and statistical analysis of Xi Jinping's policy texts on quality thoughts, this paper explores the context of $X i$ Jinping's development of quality thoughts and understands strategic position of his quality thoughts from his important narratives. Taking into account the timeliness and representative of the policy text, 42 valid texts were selected[2].

TABLE I. XI JINPING'S IMPORTANT POLICY DOCUMENTS ON QUALITY THOUGHTS (15 OUT OF 42 TEXTS, OTHERS SEE ATTACHED TABLE)

\begin{tabular}{|c|c|c|c|c|}
\hline Serial Number & Time & Speaker & Speech Topic & Coding \\
\hline First & November 6, 2013 & Xi Jinping & To Improve the Level of Teaching and Research and the Quality of Talent Cultivation & 001 \\
\hline Second & February 24, 2014 & Xi Jinping & Promoting the Construction of the Rule of Law in China & 002 \\
\hline Third & May 25, 2014 & Li Jia & Promote the construction of key projects and projects & 003 \\
\hline Fourth & July 9, 2014 & Xi Jinping & Achieve real growth without moisture & 004 \\
\hline Fifth & November 12, 2014 & Zhao Kezhi & Continuously improve the quality and level of the "three services" & 005 \\
\hline Sixth & March 30, 2015 & Xi Jinping & Ecological prosperity, then civilization will prosper & 006 \\
\hline Seventh & May 12, 2015 & Xi Jinping & Not all laws can cure the country & 007 \\
\hline Eighth & July 17, 2015 & Xia Baolong & Deeply promote the vivid practice of "four comprehensive" strategic layout in Zhejiang & 008 \\
\hline Ninth & September 9, 2015 & Xi Jinping & High quality only with high standards & 009 \\
\hline Tenth & March 9, 2016 & $\begin{array}{c}\text { Zhang } \\
\text { Jianlong }\end{array}$ & $\begin{array}{l}\text { Thoroughly study and implement the spirit of General Secretary Xi Jinping's important } \\
\text { speech on forest ecological security }\end{array}$ & 010 \\
\hline Eleventh & February 16, 2016 & Xi Jinping & $\begin{array}{c}\text { Deeply understand the strategic position of quality and vigorously promote the } \\
\text { construction of quality and strong country }\end{array}$ & 011 \\
\hline Twelfth & September 3, 2016 & Xi Jinping & Unswervingly promote green development, seek better quality and efficiency & 012 \\
\hline Thirteenth & January 24, 2017 & Xi Jinping & $\begin{array}{c}\text { Scientific planning, intensive use of resources, high-quality completion of the Winter } \\
\text { Olympics preparation work }\end{array}$ & 013 \\
\hline
\end{tabular}




\begin{tabular}{|c|c|c|c|c|}
\hline \multicolumn{4}{|c|}{ Cont. to TABLE I. } \\
\hline Fourteenth & September 15, 2017 & Xi Jinping & China quality conference xi jinping congratulatory letter & 014 \\
\hline Fifteenth & November 1, 2017 & Xi Jinping & Comprehensively improve the quality of organizational work & 015 \\
\hline
\end{tabular}

\section{A. Analysis of Framework: tools - value chain 2D framework}

Starting from the two dimensions of policy tools and chain of quality value, the two-dimensional analysis of framework of $X i$ Jinping's quality thought analysis is established. Among them, the $\mathrm{X}$ dimension is $\mathrm{Xi}$ Jinping's policy tool on quality thinking, which needs to consider the two main factors of rationality and value. The $\mathrm{Y}$ dimension is dimension of the quality value of $X i$ Jinping's quality thought and it represents the quality value that $X i$ Jinping embodied in a series of important speeches. This paper mainly analyzes the quality of $X i$ Jinping's quality by establishing an analytical framework based on $\mathrm{X}$ and $\mathrm{Y}$ dimensions[3].

\section{1) $X$ dimension: Policy Tools of Xi Jinping's Quality} Thought

Policy tool is the carrier of $X i$ Jinping's quality thought. Rothwell and Zegveid's classification of policy tools can better reflect the distribution of $X i$ Jinping's quality thoughts through the supply, demand and environmental aspects, reflecting the importance of needs of quality policy and supply. Supply-oriented policy tool in the X dimension is that the state improves the level of quality service through technological innovation, quality information service platform and quality inspection and quarantine equipment construction and enhances the quality and strength of core technologies and projects. Environmental policy tools are strictly controlled from the aspects of quality system, quality integrity and quality regulations and improve the ability of overall quality management. The supply-oriented policy tool refers to the government's purchase of quality services, market, quality supervision of market, social quality supervision and PPP mode to increase social investment in quality and create a market atmosphere of pursuing quality.

2) Y dimension: the value of Xi Jinping's quality thought

$X i$ Jinping's series of important expositions on quality issues reflect his scientific, systematic, practical and innovative quality ideas. The legal system, the party's internal governance, economic and technological innovations all highlight president Xi's advanced understanding of quality issues and his rich quality value. To deepen the construction of a quality and powerful country and use scientific theories to guide China's quality work, we must understand the quality values embodied in Xi Jinping's speech, learn the scientific methods of quality management so as to effectively improve capabilities of the quality management.

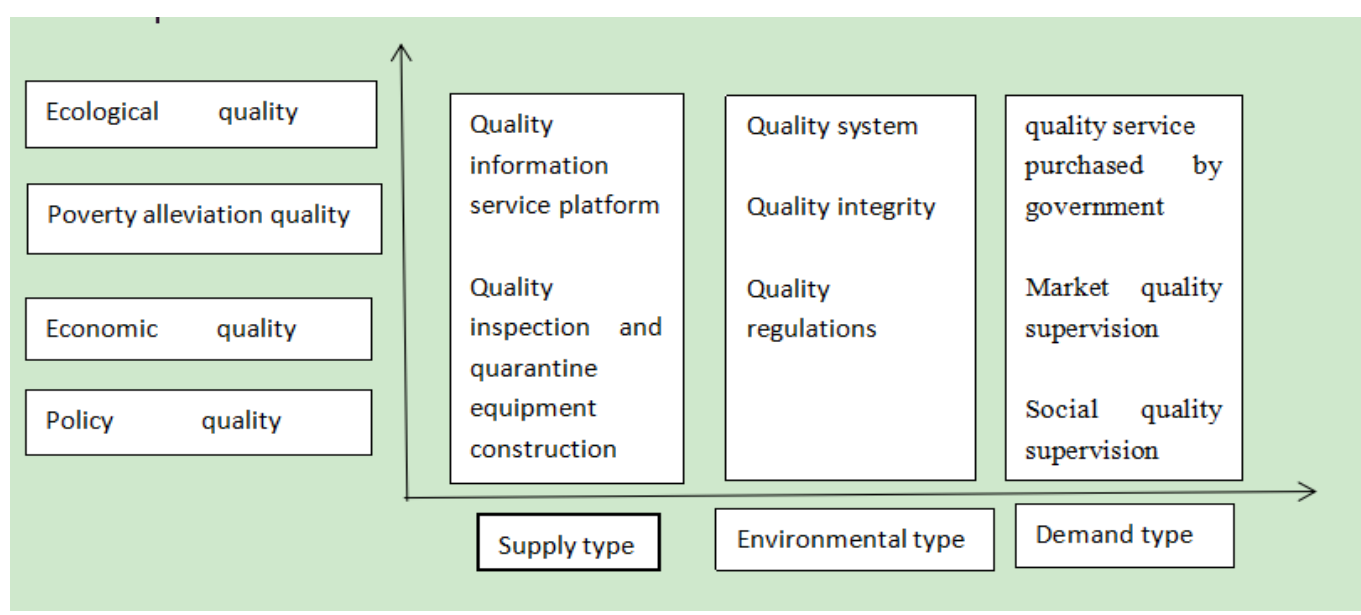

Fig. 1 X-Y dimension content analysis of Xi Jinping's quality thought (made by the two-dimensional framework of the tool-value chain)

\section{B. Text coding and data statistics}

\section{1) Text unit coding}

Firstly, the policy texts of Xi Jinping's quality thoughts are coded according to time series (see TABLE I) and then the two-dimensional analysis framework is constructed according to the quality values embodied in these policy texts and finally the content analysis unit of this paper is formed.

\section{2) Statistics}

According to the content analysis unit built, the policy tools are classified, different categories and distributions are obtained and then the factors of the value chain are considered to obtain the proportion of policy tools of $X i$ Jinping's quality thought under the tool-value chain framework. (See Fig. 1) 
TABLE II. XI JINPING'S QUALITY THOUGHT POLICY TOOL SELECTION FREQUENCY DISTRIBUTION UNDER THE TOOL-VALUE CHAIN FRAMEWORK(MADE BY TEXT STATISTICS)

\begin{tabular}{|c|c|c|c|c|c|c|c|}
\hline Policy tool & & $\begin{array}{l}\text { Policy } \\
\text { quality }\end{array}$ & $\begin{array}{l}\text { Economic } \\
\text { quality }\end{array}$ & $\begin{array}{l}\text { Poverty } \\
\text { alleviation } \\
\text { quality }\end{array}$ & $\begin{array}{l}\text { Ecological } \\
\text { quality }\end{array}$ & \multicolumn{2}{|c|}{ Ratio(\%) } \\
\hline \multirow[b]{2}{*}{ Supply type } & $\begin{array}{c}\text { Quality information service } \\
\text { platform }\end{array}$ & 20 & 16 & 38 & 14 & 12.57 & \multirow[b]{2}{*}{18.14} \\
\hline & $\begin{array}{c}\text { Quality inspection and } \\
\text { quarantine equipment } \\
\text { construction }\end{array}$ & 3 & 11 & 10 & 15 & 5.57 & \\
\hline \multirow{3}{*}{$\begin{array}{l}\text { Environmental } \\
\text { type }\end{array}$} & Quality system & 30 & 28 & 36 & 27 & 17.29 & \multirow{3}{*}{44.86} \\
\hline & Quality integrity & 35 & 16 & 18 & 9 & 11.14 & \\
\hline & Quality regulations & 32 & 28 & 30 & 25 & 16.43 & \\
\hline \multirow{4}{*}{ Demand type } & $\begin{array}{c}\text { Quality service purchased } \\
\text { By government }\end{array}$ & 1 & 9 & 14 & 5 & 4.14 & \multirow{4}{*}{37.0} \\
\hline & Market quality supervision & 20 & 20 & 30 & 27 & 13.86 & \\
\hline & Social quality supervision & 22 & 10 & 30 & 27 & 12.72 & \\
\hline & PPP mode & 4 & 18 & 20 & 2 & 6.28 & \\
\hline Proportion & Ratio(\%) & 23.86 & 22.29 & 32.29 & 21.56 & 100 & 100 \\
\hline
\end{tabular}

\section{Data analysis and results}

The value of Xi Jinping's quality thought is mainly reflected in the quality of poverty alleviation and policy quality. Among the four types of quality values, policy quality accounts for $23.86 \%$, poverty alleviation quality accounts for the largest proportion, reaching $32.29 \%$, economic quality accounts for $22.29 \%$ and ecological quality lists the next. With the economic and social development shifting from the speed era to the quality era, China must achieve the grand goal of building a well-off society in an all-round way and the quality of poverty alleviation must be the top priority. Winning the fight against poverty is not only a matter of national economy and people's livelihood, but also a greatly Chinese dream. It is one of the strategic plans for the direction of social precision governance. Based on the latest development situation, general secretary Xi Jinping systematically put forward the strategy of precise poverty alleviation and accurate poverty alleviation and summed up China's long-term poverty alleviation experience, forming Xi Jinping's precise poverty alleviation thinking with Chinese characteristics. He proposed the "six precisions" in precise poverty alleviation and advocated spiritual poverty alleviation, endogenous poverty alleviation and scientific poverty alleviation. At the same time, the introduction of a series of policy documents such as "Service Industry Innovation Development Outline" and "Metrics Development Plan (2013-2020)" marks the continuous improvement of China's quality system and reflects the high policy quality.

(1) The policy tools selected by Xi Jinping's quality thought in the $\mathrm{X}$ dimension are more inclined to environmental and demand-oriented policy tools. Among the three policy tools, the number of environmental policy tools accounts for the largest, reaching $44.86 \%$, followed by demand-based policy tools, accounting for $37 \%$. Supply policy tools are the least used, only $18.14 \%$. During determining strategic position of quality, Xi Jinping has made many important speeches. In view of the lack of China's institutional mechanisms and the low efficiency of quality policy implementation, Xi Jinping advocates the promotion and improvement of quality laws and regulations, establishing a quality punitive system, studying and formulating legal quality promotion laws. The quality punitive system should be established. The Law on the promotion of legal quality should be researched and formulated.
Based on the relatively weak national quality values, he proposed to speed up the establishment of a market-oriented quality credit evaluation system and promote the marketized, procedural and institutional development of quality and integrity values. The quality system is the carrier of ability of quality management and the quality system content embodied in $X i$ Jinping's quality thought shows the correctness of $X i$ Jinping's quality thinking.

(2) The distribution of supply-oriented policy tools is uneven. Among the types of tools, the quality information service platform accounted for $12.57 \%$, while the quality inspection and quarantine equipment construction accounted for only 5.57\%. This ratio gap reflects the country's excessive emphasis on the construction of sharing platform of quality information when establishing a quality management system and improving the quality level and insufficient investment in the basic facilities for quality inspection and testing. In order to achieve more effective improvement of the quality level, it is necessary to establish a national platform of product quality credit and improve the national product quality integrity database and application system built by the product quality credit record. By establishing a Chinese commodity information service platform, commodity information public services that combine product management and product services will be realized. By establishing a benchmark platform for industrial and informational quality, we will provide a professional communication platform for industry enterprises, so that the quality representative experience will take root in more enterprises.

\section{The IMPLications of Xi JinPing's Quality ThOUght TEXT ANALYSIS FOR CHINA'S QUALITY DEVELOPMENT IN THE NEW ERA}

Analysis of the value of Y-Xi Xi Jinping's quality thoughts, it can be concluded that $X i$ Jinping's quality thoughts are mainly reflected in the field of poverty alleviation and related policy formulation. The quality of poverty alleviation is the top priority of building a well-off society in 2020, which directly affects the quality of China's economic development. To realize a comprehensive well-off society in the true sense, we must make up for the shortcomings and upgrade our country's quality and strength in various fields. Poverty alleviation is a 
major national strategy that General Secretary Xi Jinping has made towards a comprehensive well-off society in light of China's development status quo. From a vertical perspective, from the development of the precise poverty alleviation policy in 2013 to the current pattern of poverty alleviation, the work content of poverty alleviation is constantly changing and the methods of poverty alleviation are also being further improved. In the face of the arduous task of achieving comprehensive poverty alleviation in 2020, we should continuously summarize the political practices we have gained, improve systems of relevant policy and solve outstanding problems encountered in the process of poverty alleviation. For example, the phenomenon included inaccurate poverty alleviation targets and unreasonable distribution of poverty alleviation funds still exists. We must put more effort into industrial poverty alleviation , promote the growth of exogenous power and at the same time integrate poverty alleviation funds to improve the effectiveness of poverty alleviation. On the other hand, it is suitable for considering the causes of poverty in poverty alleviation areas in China in order that the poverty alleviation policy is closer to the actual situation in rural areas. Methods of poverty alleviation can be made to adjust to China's new urban-rural relationship. It is timely found that new urban-rural contradictions appear in the process of urban and rural development so that research countermeasures can be resolved timely.

Policy is the most authoritative and credible guidance in the period of development of the country. In the dimension of $X i$ Jinping's quality thought value, the quality of policy accounts for $23.86 \%$, which is second only to the ratio of poverty alleviation quality. This shows that the quality of the policy reflects $X i$ Jinping's quality thinking to a large extent. With the economic transformation and development entering an in-depth adjustment stage, poverty alleviation has entered a critical period and international trade competition has become increasingly fierce. In the face of complex and domestic and international situations, China needs more strategic and leading policy support and leadership. The quality policy proposed by president $\mathrm{Xi}$ is in line with the country's development needs and it is suitable for China's national conditions and provides a basis for governance and guidance for the future development of China. In order to better meet the challenges and enhance China's quality and strength, all relevant quality administrative departments should be classify and summarize the series of important policy documents and the general secretary's discourse on quality issues in order to form a systematic policy category. Considering the regional short board effect, a refined government quality system of management should be established so as to build solid and institutional support for the quality of the country's strategy.

One of the reasons for the uneven distribution of supply-oriented policy tools is that China's economic development starts late and does not have a basic awareness of quality development. The domestic low-quality and low-price market environment is not conducive to the transmission of quality signals and there is no market competition mechanism for the survival of the fittest, which does not reflect the market competitive advantage of high-quality products. At the same time, the construction of professional platforms in China's quality field lags behind and there is no mature technological development environment. By analyzing, I hope that relevant parts of the country can increase capital investment in professional testing platforms, quality information service platforms, testing institutions and improve the technical standards for quality testing in order to enable professional technology platforms to play their professional voice in the field of quality and contribute to the development of quality.

\section{SUMMARY}

Since the reform and opening up, Chinese quality work has been steadily moving forward, the quality of products and services has improved significantly and the quality of engineering has been continuously improved. Despite this, there is still a lot of room for development in terms of core technologies and brand advantages compared to developed countries. In order to fill the shortcomings of quality and realize the road of quality rise of big countries, this paper summarizes the essence of the quality of General Secretary $X i$ Jinping through the quantitative analysis of 42 texts. It provides a strongly theoretical basis and policy compliance for the goal of achieving a strong quality country and provides guidance for Chinese development in the future. Then it is helpful to improve ecological quality, economic quality, legal quality, poverty alleviation quality in order to achieve long-term development of Chinese quality undertakings.

\section{ACKNOWLEDGEMENT}

This research was financially supported by the National Social Science Fund of 2018 (18BZZ084) "Research on Measurement and Capacity Improvement of Big Poverty Alleviation in Southwest", Humanities and Social Science of Ministry of Education of 2015 (15XJC810001) "Research on Anti-poverty Governance Model of Multi-center Collaboration in Depressed Areas-An Empirical Study Based on the Mountainous Areas in Western Yunnan "and Yunnan philosophy and social science project "Research on the Model Innovation of Precision Poverty Alleviation in the Poor Area of Yunnan Province under the Framework of LAD" (KKSK201758004).

\section{REFERENCE}

[1] National quality inspection system. Do not forget the initial heart, fight for the quality of the country.

[2] Hui Gongjian, Li Ming. The Application of Content Analysis in Internet Research-From the Perspective of Comparison with Traditional Media Content Analysis[J], Library Science Research, 2011(5).

[3] Yang Zhijun, Yu Xu, Wang Ruoxue. Tool Preference and Path Optimization of Environmental Governance Policy-Based on Content Analysis of 43 Policy Texts[J].Journal of Northeastern University, 2017(3): 276-283.

[4] Liu Qiangqiang, Mo Lan. A Textual Quantification Study of Guizhou Province's Poverty Alleviation Policy from the Perspective of Policy Tools[J]. Fujian Administration, 2016(5):22-30. 
Appendix

\begin{tabular}{|c|c|c|c|c|}
\hline Serial Number & Time & Speaker & Speech Topic & Coding \\
\hline First & $\begin{array}{l}\text { November 6, } \\
2013\end{array}$ & Xi Jinping & $\begin{array}{c}\text { To Improve the Level of Teaching and Research and the Quality of } \\
\text { Talent Cultivation }\end{array}$ & 001 \\
\hline Second & $\begin{array}{l}\text { February 24, } \\
2014\end{array}$ & Xi Jinping & Promoting the Construction of the Rule of Law in China & 002 \\
\hline Third & $\begin{array}{l}\text { May 25, } \\
2014\end{array}$ & Li Jia & promote the construction of key projects and projects & 003 \\
\hline Fourth & July 9, 2014 & Xi Jinping & Achieve real growth without moisture & 004 \\
\hline Fifth & $\begin{array}{c}\text { November } \\
12,2014 \\
\end{array}$ & Zhao Kezhi & Continuously improve the quality and level of the "three services" & 005 \\
\hline Sixth & $\begin{array}{l}\text { March 30, } \\
2015\end{array}$ & Xi Jinping & Ecological prosperity, then civilization will prosper & 006 \\
\hline Seventh & $\begin{array}{l}\text { May 12, } \\
2015\end{array}$ & Xi Jinping & Not all laws can cure the country & 007 \\
\hline Eighth & July 17, 2015 & Xia Baolong & $\begin{array}{l}\text { Deeply promote the vivid practice of "four comprehensive" strategic } \\
\text { layout in Zhejiang }\end{array}$ & 008 \\
\hline Ninth & $\begin{array}{l}\text { September 9, } \\
2015\end{array}$ & Xi Jinping & High quality only with high standards & 009 \\
\hline Tenth & $\begin{array}{l}\text { March 9, } \\
2016\end{array}$ & $\begin{array}{c}\text { Zhang } \\
\text { Jianlong }\end{array}$ & $\begin{array}{c}\text { Thoroughly study and implement the spirit of General Secretary Xi } \\
\text { Jinping's important speech on forest ecological security }\end{array}$ & 010 \\
\hline Eleventh & $\begin{array}{l}\text { February 16, } \\
2016\end{array}$ & Xi Jinping & $\begin{array}{l}\text { Deeply understand the strategic position of quality and vigorously } \\
\text { promote the construction of a quality and strong country }\end{array}$ & 011 \\
\hline Twelfth & $\begin{array}{l}\text { September 3, } \\
2016\end{array}$ & Xi Jinping & $\begin{array}{l}\text { Unswervingly promote green development, seek better quality and } \\
\text { efficiency }\end{array}$ & 012 \\
\hline Thirteenth & $\begin{array}{c}\text { January 24, } \\
2017 \\
\end{array}$ & Xi Jinping & $\begin{array}{l}\text { Scientific planning, intensive use of resources, high-quality } \\
\text { completion of the Winter Olympics preparation work }\end{array}$ & 013 \\
\hline Fourteenth & $\begin{array}{l}\text { September } \\
15,2017\end{array}$ & Xi Jinping & China Quality Conference Xi Jinping Congratulatory Letter & 014 \\
\hline Fifteenth & $\begin{array}{l}\text { November 1, } \\
2017\end{array}$ & Xi Jinping & comprehensively improve the quality of organizational work & 015 \\
\hline Sixteenth & $\begin{array}{c}\text { December } \\
22,2017 \\
\end{array}$ & Xi Jinping & $\begin{array}{l}\text { Guiding Guangdong's high-quality development with Xi Jinping's } \\
\text { new era of socialist economic thought with Chinese characteristics }\end{array}$ & 016 \\
\hline Seventeenth & $\begin{array}{c}\text { December } \\
23,2017 \\
\end{array}$ & Xi Jinping & $\begin{array}{c}\text { From "Made in China" to "Created in China" - China's economy has } \\
\text { entered a new era }\end{array}$ & 017 \\
\hline Eighteenth & $\begin{array}{c}\text { December } \\
27,2017\end{array}$ & Xi Jinping & $\begin{array}{l}\text { Promoting the construction of rural roads into a new stage of high } \\
\text { quality development }\end{array}$ & 018 \\
\hline Nineteenth & $\begin{array}{l}\text { December } \\
29,2017\end{array}$ & Xi Jinping & $\begin{array}{c}\text { Composing a new chapter in the new era of rural comprehensive } \\
\text { revitalization }\end{array}$ & 019 \\
\hline Twentieth & $\begin{array}{l}\text { January 4, } \\
\quad 2018\end{array}$ & $\begin{array}{c}\text { Li } \\
\text { Hongzhong }\end{array}$ & $\begin{array}{c}\text { Resolution on Implementing the Internship in the New Era of } \\
\text { Modern Times and the Socialist Economic Thought with Chinese } \\
\text { Characteristics Promoting High-Quality Development }\end{array}$ & 020 \\
\hline $\begin{array}{c}\text { The } \\
\text { twenty-first }\end{array}$ & $\begin{array}{l}\text { anuary 9, } \\
2018 \\
\end{array}$ & Liu Shi & $\begin{array}{l}\text { Don't forget the beginning of the heart, remember the mission, open } \\
\text { a new journey of quality and strong country construction }\end{array}$ & 021 \\
\hline $\begin{array}{l}\text { The twenty } \\
\text { second }\end{array}$ & $\begin{array}{l}\text { January 12, } \\
2018\end{array}$ & Chen Miner & Leading strictly the party from governance to the depths & 022 \\
\hline Twenty-third & $\begin{array}{l}\text { January 13, } \\
2018 \\
\end{array}$ & Lu Xinshe & $\begin{array}{l}\text { High standard and high quality, open four provincial teams for } \\
\text { democratic life meeting }\end{array}$ & 023 \\
\hline $\begin{array}{l}\text { The twenty } \\
\text { fourth }\end{array}$ & $\begin{array}{l}\text { January 27, } \\
2018\end{array}$ & Chen Miner & $\begin{array}{l}\text { Striving to promote the high quality development of Chongqing in } \\
\text { the new era }\end{array}$ & 024 \\
\hline Twenty-fifth & $\begin{array}{l}\text { February 16, } \\
2018\end{array}$ & Xi Jinping & Putting the quality of poverty alleviation first & 025 \\
\hline Twenty-sixth & $\begin{array}{l}\text { February 22, } \\
2018 \\
\end{array}$ & $\begin{array}{c}\text { Wang } \\
\text { Dongfeng }\end{array}$ & $\begin{array}{c}\text { Striving to build Xiong'an New District into a national model to } \\
\text { promote high-quality development }\end{array}$ & 026 \\
\hline Twenty-seventh & February 24, & Xi Jinping & Implementing high-quality development in all aspects of the whole & 027 \\
\hline
\end{tabular}




\begin{tabular}{|c|c|c|c|c|}
\hline & 2018 & & process & \\
\hline Twenty-eighth & $\begin{array}{l}\text { March 6, } \\
2018\end{array}$ & Xi Jinping & $\begin{array}{c}\text { Steady Promotion of High-quality Economic Development and } \\
\text { Steady Promotion of Poverty Alleviation }\end{array}$ & 028 \\
\hline Twenty-ninth & $\begin{array}{l}\text { March 15, } \\
2018\end{array}$ & Xi Jinping & Xi Jinping talked about 20 key words of "high quality development & 029 \\
\hline Thirtieth & $\begin{array}{l}\text { March 27, } \\
\quad 2018\end{array}$ & Li Jiheng & $\begin{array}{c}\text { Keeping in mind General Secretary Xi Jinping's instructions and } \\
\text { make solid strides in high-quality development and poverty } \\
\text { alleviation }\end{array}$ & 030 \\
\hline Thirty-first & April 4, 2018 & Xi Jinping & Development Turns to High Quality & 031 \\
\hline Thirty-second & $\begin{array}{l}\text { April 19, } \\
2018\end{array}$ & Li Jinbin & $\begin{array}{c}\text { In-depth Study and Implementation of General Secretary Xi } \\
\text { Jinping's Important Strategic Thought on Poverty Alleviation and } \\
\text { Development }\end{array}$ & 032 \\
\hline Thirty-third & $\begin{array}{l}\text { April 28, } \\
2018 \\
\end{array}$ & Li Guoying & $\begin{array}{l}\text { Greater efforts and coordination to promote high-quality } \\
\text { development of the Yangtze River Economic Zone }\end{array}$ & 033 \\
\hline Thirty-fourth & May 3, 2018 & $\begin{array}{c}\text { Chen } \\
\text { Guoguo }\end{array}$ & $\begin{array}{c}\text { Firmly Focusing on the General Goal to Promote the High-quality } \\
\text { Development of the Region's Economy }\end{array}$ & 034 \\
\hline Thirty-fifth & $\begin{array}{l}\text { May } 16, \\
2018\end{array}$ & Liu Qi & $\begin{array}{l}\text { Keeping in mind General Secretary Xi Jinping's instructions and } \\
\text { promote the high-quality development of Jiangxi's economy }\end{array}$ & 035 \\
\hline Thirty-sixth & $\begin{array}{l}\text { May 21, } \\
2018 \\
\end{array}$ & Xi Jinping & $\begin{array}{c}\text { The Decision to Write a New Chapter of High Quality Development } \\
\text { in Hubei Province in the New Era }\end{array}$ & 036 \\
\hline Thirty-seventh & $\begin{array}{l}\text { June 25, } \\
2018\end{array}$ & $\begin{array}{l}\text { Wang } \\
\text { Dongfeng }\end{array}$ & $\begin{array}{c}\text { Guided by Xi Jinping's Socialist Thought with Chinese } \\
\text { Characteristics in the New Era, we should comprehensively promote } \\
\text { the high-quality development of private economy. }\end{array}$ & 037 \\
\hline Thirty-eighth & July 12, 2018 & Xi Jinping & $\begin{array}{c}\text { In the stage of high-quality development, it is especially necessary to } \\
\text { practice Xi Jinping's ecological civilization thought. }\end{array}$ & 038 \\
\hline Thirty-ninth & July 24, 2018 & $\begin{array}{c}\text { Zhang } \\
\text { Qingwei }\end{array}$ & $\begin{array}{l}\text { Compacting compaction responsibility, high standard and high } \\
\text { quality, make every effort to implement inspection and rectification. }\end{array}$ & 039 \\
\hline Fortieth & $\begin{array}{l}\text { August 23, } \\
2018 \\
\end{array}$ & Xi Jinping & $\begin{array}{l}\text { Understanding Xi Jinping's Important Speech on Propaganda and } \\
\text { Ideological Work }\end{array}$ & 040 \\
\hline Forty-first & $\begin{array}{l}\text { August 25, } \\
2018 \\
\end{array}$ & Moses Chan & $\begin{array}{c}\text { Striving to Promote the Leaping Development of Yunnan's Economy } \\
\text { with High Quality }\end{array}$ & 041 \\
\hline Forty-second & $\begin{array}{l}\text { August 28, } \\
2018\end{array}$ & Xi Jinping & $\begin{array}{c}\text { Promoting the transformation of "one belt and one road" to high } \\
\text { quality development }\end{array}$ & 042 \\
\hline
\end{tabular}

